DOI https://doi.org/10.32837/app.v0i65.300

УДК 321:316.483

\author{
Ю. В. Завгородня \\ ORCID ID: https://orcid.org/0000-0003-3500-8638 \\ кандидат політичних наук, \\ доцент каредри політичних теоріӥ \\ Національного університету «Одеська юридична академія»
}

\title{
ФОРМИ ВПЛИВУ НА ПОЛІТИЧНИЙ КОНФЛІКТ: ТЕОРЕТИЧНИЙ АНАЛІЗ
}

Особливості розвитку політичного процесу в рамках протиборств, непорозумінь і протидії містять специфічні ознаки свого розвитку, функціонування та завершення. Сутність такого завершення буде сприяти освідомленню подальшого формування політичних подій та взаємодії суб'єктів політичного протиборства.

Зводячи політичний конфлікт до мінімальної активності суб'єкти політики вдаються до механізмів, які сприятимуть зменшенню напруги між сторонами та в суспільстві загалом. Вплив на політичний конфлікт може бути різним на різних етапах, а тому варто визначити найбільш вживаніші в практичному використанні, а саме: запобігання, регулювання, управління, розв' язання, придушення чи завершення.

3 огляду на актуалізацію питання щодо характеристики можливих варіантів впливу на політичний конфлікт, метою дослідження є розмежування в науковому вжитку понять, подібних за звучанням, але різних за внутрішнім наповненням, які характеризують процеси впливу на конфліктний процес у політиці, їх порівняльний аналіз та наукова необхідність трактування для доцільного практичного використання на різних етапах розвитку конфлікту з урахування насильницької та ненасильницької складової частини протікання протидії сторін.

Питання щодо теоретичного дослідження політичних конфліктів розробляли вітчизняні та зарубіжні автори, а саме: В. Мандрагель, Л. Герасимова, М. Панова, О. Сахань, Ю. Шайгородський, М. Дойч, І. Станкевич, К. Ващенко, В. Корнієнко, Л. Герасіна та ін.

3 моменту зародження різних форм взаємодії в суспільстві між людьми конфлікти є невід'ємною частиною розвитку людства. Усі спроби впливу на конфлікту взаємодію здійснювалися лише локально окремими країнами світу на власний розсуд, а лише в середині XX ст. Організація Об'єднаних Націй нормативно затверджує ключову мету будь-якої суперечки, а саме ст. 33 Статуту ООН регламентовано мирне врегулювання суперечок. Стаття роз'яснює, що учасники суперечки, які своїми діями можуть негативно впливати на міжнародний мир та безпеку, зобов'язані намагатися розв'язати суперечку шляхом переговорів, огляду, медіаторства, примирення сторін, судового розгляду та іншими мирними засобами на власний розсуд (Статут ООН, 1963, ст. 33).

Звичайно, усі форми впливу на політичний конфлікт мають особливості використання залежно від різних ознак цього конфлікту, стадії та значимості для суспільства. На початковій стадії розвитку політичного конфлікту, так званій передконфліктній стадії, вплив на політичний конфлікт може відбуватись у формі запобігання. Тому запобігання конфліктів має стадійну приналежність та належить до етапу попередження політичних конфліктів та створення умов, щоб інтереси сторін, які містять кардинальні відмінності не звести до етапу безпосередньої протидії сторін.

Найчастіше запобігання використовується до конфлікту інтересів як найефективніша форма впливу на протиборство суб'єктів політики. Загалом можна виділити певні правила поведінки, які допоможуть ефективно запобігати протиборству суб'єктів політики, а саме: не доводити громадян чи групи зацікавлених осіб до критично високого рівня нестабільності, які спричиняють дезінтеграційні процеси; важливо моніторити інформацію про найбільш гострі проблеми в політичному та економічному напрямах, які стосуються основних групи населення; пам'ятати про ідеологічні орієнтири різних груп населення; моніторити інформацію про суспільно значимі політичні конфлікти, причини їх виникнення та конфліктуючі сторони. 
Найважливішим фактором запобігання політичних конфліктів є володіння певними можливостями: вплив, авторитет, політична поля, фінансові ресурси, матеріальні ресурси, людські ресурси, за допомогою яких можна реально вплинути на недопущення активної фази конфлікту.

Щодо нормативного регулювання у вітчизняному законодавстві є погляди на конфлікт інтересів у рамках Закону України «Про запобігання корупції», в якому здійснено розмежування конфлікту інтересів на потенційний та реальний. А тому, відповідно, закон визначає такі форми впливу на політичний конфлікт, як запобігання та врегулювання (Закон, 2014, с. 1).

Також важливими та вживаними формами впливу на політичний конфлікт є регулювання та врегулювання. Досить часто ці поняття використовують як тотожні, або суміжні, однак якщо розглянути сам процес протікання конфліктної взаємодії, то можна визначити, що регулювання конфлікту - це уся сукупність дій сторін протиборства, спрямованих на вичерпання конфлікту, а врегулювання конфлікту - це кінцева фаза протиборства, яка приводить до позитивного завершення конфліктної взаємодії, яка сприяє подальшому співробітництву конфліктуючих сторін. Тобто регулювання - це низка процедур, які спрямовані на вирішення конфлікту, однак вони можуть і не привезти до бажаного результату. Своєю чергою врегулювання конфлікту - це ті методи, які приводять до бажаного завершення конфлікту.

Окрім того, загальноприйнятим правилом у процесі розв'язання політичного конфлікту $\epsilon$ намагання усунути суперечності між сторонами за участю третьої сторони, яка допомагає сторонам визначити усі негативні аспекти конфлікту, які можуть мати місце в разі відсутності між сторонами консенсусу чи компромісу.

Для політичної практики таке тлумачення процесів впливу на конфліктуючі сторони $є$ досить показовим на прикладі сучасної української історії. Конфлікт між суб'єктами влади та громадянами, який у суспільстві називається Революцією Гідності, чітко показує, що всі методи, до яких вдавалася влада, щоб завершити конфлікт, не були ефективними, а саме: придушення конфлікту, зміна виконавчої гілки влади, зміни законодавства України. Тому усі спроби вплинути на процес розвитку та завершення конфлікту не призвели до врегулювання конфлікту вибраними діями.

Однак врегулювання цього конфлікту відбулось у межах політико-правових дій, а саме шляхом позачергових виборів Президента України та позачергових виборів до Верховної Ради України. Суб'єкти, які на той момент представляли владні позиції шляхом політичної волі, яка в певних межах не відповідала нормам закону (а саме законний шлях завершення повноважень чинного президента України, який покинув територію країни), але відповідала задоволенню інтересів населення, призначили позачергові вибори Президента України. Саме ці вибори відбулися з високою явкою громадян та визнанням усіх процедур щодо такого виборчого процесу, що слугувало механізмом політико-правового врегулювання цього політичного конфлікту.

У політичній науці виділяють різні методи, за допомогою яких здійснюється мирний вплив на політичний конфлікт: уникнення, відкладання, арбітраж, переговори та ін. Основна мета будь-якого методу - це вплив на конфлікт таким чином, щоб він дійшов до завершення активної фази протиборства та перенаправив активність у межі співробітництва сторін (Станкевич, 2007, с. 70).

Окрім того, в процесі врегулювання політичного конфлікту виділяють підходи науково розтлумачені, які сприяють роз'ясненню політичних ситуацій та обгрунтовують механізм впливу на конфліктну активність сторін протиборства. До таких наукових підходів варто зарахувати морально-правовий підхід, силовий підхід, реалістичний підхід, ідеалістичний підхід, компромісний підхід, консенсусний підхід, інтегративний підхід. Вони своєю чергою поділяються на насильницькі та ненасильницькі форми впливу на політичний конфлікт (Ващенко, Корнієнко, 2010, с. 15). В усіх демократичних та правових державах політичний конфлікт вирішується, як правило, шляхом ненасильницьких методів. Однак дедалі частіше в сучасному світі політичні конфлікти переходять у фазу військового протиборства з утворенням республік та мінідержав, які не визнані на міжнародній арені.

Ще однією часто вживаною категорією впливу на політичний конфлікт є методика управління політичним конфліктом. Управління політичним конфліктом варто розглядати як 
один із методів регулювання конфлікту, а тому під час теоретичної характеристики процесів впливу на політичний конфлікт варто чітко розмежовувати форми впливу та безпосередні методи в рамках окремої категорії.

Управління політичним конфліктом допомагає надати практичну підтримку політичним діячам, щоб у ненасильницькій формі розв'язати політичний конфлікт. Управління в конфліктній взаємодії може містити небезпечну складову частину протиборства, оскільки політичний конфлікт не завжди можна прогнозувати, а тому є небезпека хаосу та безконтрольності в окремих видах конфлікту.

Однак управління політичним конфліктом містить низку позитивних аспектів щодо впливу на політичний конфлікт, а саме: змогу розуміти межі, в яких діють суб'єкти протиборства та можливо допустимі політичні атаки, до яких можуть вдаватись політики в межах власних інтересів. Актуальність управлінського характеру конфлікту зростає в сучасних українських реаліях, оскільки політичні діячі можуть вдаватись до використання профінансованих мітингів щодо окремих питань та рішень. Основною метою таких дій є відвернення уваги від більш значного політичного рішення або блокування політичних рішень загалом.

Така управлінська політична конфронтація уже стає сучасною практикою політичних груп із різними поглядами на прийняття політичних рішень. Однак така діяльність містить загрози для суспільства та державного апарату щодо настання затяжної кризи взаємодії між владою та громадянами. Недовіра до політичних сил, відсутність авторитету влади перед суспільством, пасивність щодо прийняття політичних рішень - ознаки кризового стану, які суспільство намагалось подолати на останніх виборах до Верховної Ради України та виборах Президента України.

Тому у влади в сучасній Україні великий відсоток кредиту довіри суспільства, який вони зобов' язані використати ефективно для подолання кризи непорозуміння між владою та суспільством.

Найбільш вживаним елементом, який позитивно впливає на процес взаємодії сторін протиборства, є розв' язання політичного конфлікту.

Під цим поняттям варто розуміти сумісну діяльність учасників конфлікту, яка спрямована на протидію та врегулювання проблеми, що спричинила зіткнення цих сторін. Як правило, розв'язання конфлікту передбачає спільну діяльність сторін, спрямовану на створення умов, які задовольнять обидві сторони, з метою повного вичерпання конфліктної активності учасників.

У сучасних умовах досить важко об' єктивно визначити ставлення сторін до можливості розв' язання політичного конфлікту, оскільки сторони публічно зобов'язані визнати себе стороною конфлікту, а в сучасних конфліктах виникають спотворені суб'єктні характеристики учасників конфліктної взаємодії. Яскравим прикладом такого гібридного суб'єктного складу є військовий конфлікт на сході України, де учасник конфлікту (військові групи Російської Федерації) визначає себе як медіатор, тобто посередник, який публічно підтримує мир на конфліктуючій стороні і одночасно надає гуманітарну військову допомогу одній зі сторін протиборства.

У такій політичній ситуації цілковите розв'язання політичного конфлікту не можливе. У такому конфлікті можливе замороження військової активності сторін, але не повне політичне та правове врегулювання.

Для розв'язання як найважливішої мети конфлікту варто оцінити ступінь вирішення проблеми, яка зіткнула різні інтереси.

На думку американського вченого М. Дойча, основною ознакою успішного розв'язання протиборства є задоволення сторін результатами його завершення (Дойч, 1948, с. 15).

Тому активність сторін конфлікту варто повністю досліджувати, враховувати усі аспекти та побажання сторін, тоді буде більше шансів для стабілізації взаємодії між учасниками, а ймовірність щодо розвитку нового конфлікту буде дуже низькою. Важливо, щоб під час вирішення конфлікту сторони повністю розкривали усі аспекти невдоволення та непорозуміння.

Однак, якщо в конфлікті перемагає сторона, яка була повністю права, - це показник позитивного аспекту конфлікту, затвердження справедливості та істини. Разом із тим нехтувати інтересами неправої сторони не варто, доцільно спробувати перенаправити мотивацію опонента, щоб надалі запобігти конфліктам між цими суб' єктами (Герасіна, 2012, с. 34). 
Отже, поняття регулювання, розв'язання та врегулювання - це поняття, близькі за звучанням, але різні за сутнісним, процесуальним та суб' єктним наповненням.

Окрім цих вагомих факторів впливу, які використовуються в активний період розвитку політичного конфлікту, варто виділити поняття, що пов'язані кінцевим етапом конфлікту, однак мають різні механізми їх досягнення - це придушення та завершення політичного конфлікту.

Придушення політичного конфлікту варто розглядати як один зі способів насильницького врегулювання конфлікту. Однак варто зазначити, що в цивілізованому світі йдеться про використання придушення лише за наявності ознак несанкціонованого протиправного зібрання людей, які своєю діяльністю шкодять державі та загалом усім громадянам, оскільки дестабілізують ситуацію в суспільстві. У разі використання методу придушення суб' єкти політики зобов'язанні здійснювати професійне керівництво такою операцією, оскільки жорстоке поводження та надмірна силова атака можуть стати агресією та збілышенням масштабів протистояння.

Загалом до методу придушення в сучасних політичних протистояннях сторони вдаються досить рідко і це, як правило, країни з перехідним політичним режимом або тоталітарні держави. Однак, якщо країна має низький рівень розвитку та обмежену політичну свідомість, то такий метод буде мати форму дисциплінарної відповідальності однієї із сторін конфлікту. Тоді діятиме принцип «хто сильніший чи впливовіший, той і правий». Придушення не передбачає врахування інтересів, поступки сторін, домовленості чи консенсус, а тому цей метод $є$ небезпечним та непередбачуваним для подальших взаємовідносин суб'єктів конфлікту. Тут немає обмежень сторін у дозволеному.

Придушення може стати завершенням конфлікту, тобто визнанням однієї зі сторін своєї поразки, а може стати причиною створення так званої «петлі зворотного зв' язку» повернення конфліктної взаємодії на передконфліктну стадію з новими силами та новими масштабами конфлікту.

Саме власне завершення політичного конфлікту може настати через врегулювання конфлікту насильницьким/ ненасильницьким шляхом або втрату одного з елементів конфлікту: об'єкта або суб'єкта. У такому разі конфлікт вже не має політичної цінності та актуальності.

Якщо конфлікт завершено за допомогою врегулювання будь-яким методом, ймовірність його повторного розвитку щодо цього об'єкта мінімальна, однак у разі завершення конфлікту ймовірність повторного розвитку конфліктної активності за їх об'єктом висока, а тому після завершення конфлікту варто стежити за діяльністю суб'єктів політики, їх пріоритетними напрямами діяльності та політичними рішеннями.

Тобто завершення політичного конфлікту - це стадія розвитку протиборства сторін щодо політичного рішення чи важелів впливу в політиці, яка передбачає повне припинення активних, публічних та латентних атак сторін протиборства. Ця стадія свідчить лише про те, що сторони конфлікту припиняють шкодити своӥми діями опоненту та суспільству загалом.

Отже, враховуючи усе вищезазначене, можемо дійти висновку, що політичний конфлікт у процесі стадійного розвитку можна піддавати різним факторам впливу, які актуальні та характерні для окремих фаз у протиборстві. А тому чим якіснішим буде такий вплив, тим швидшим буде завершення конфлікту.

Усі сучасні політичні дослідження спрямовані на полегшення протікання конфлікту як для учасників, так і для пересічних громадян, оскільки політичні конфлікти впливають не лише на учасників протиборства, а й на суспільство загалом. Відшукання істини в суперечці це найцінніша складова частина будь-якої взаємодії з метою покращення політичної системи та зміни сприйняття політичних процесів.

Конфліктна взаємодія - це норма демократичного розвитку будь-якого суспільства. Вміння дипломатично врегульовувати суперечності, визнавати поразки та публічно вибачатись шлях до позитивних змін. Державні органи - це не апарат ідеальних людей, а представники влади, які мають слугувати прикладом для більшості громадян у виборі варіанта поведінки в непорозуміннях, труднощах та проблемах.

Лimepamypa:

Закону України «Про запобігання корупції». URL: https:/ / zakon.rada.gov.ua/laws/show/1700-18. 
Ващенко К.О., Корнієнко В.О. Політологія для вчителя. URL: https://web.posibnyky.vntu.edu.ua/ fmib/13vashenko_politologiya_dlya_vchitelya/194.htm.

Конфліктологія : навч. посібник / Л.М. Герасіна, М.П. Требін, В.Д. Воднік та ін. Харків : Право, 2012. 128 с. Дойч М. Хрестоматія по політології. Вирішення конфлікта (конструктивні і деструктивні процеси). URL: https://www.gumer.info/bibliotek_Buks/Psihol/Konflikt/05.php.

Станкевич І.П. Політичний конфлікт та технологія його запобігання. Вісник Київ. наи. ун-му ім. Тараса Шевченка. Серія: Філософія. Політологія. 2007. Вип. 87-88. С. 70-73.

Станкевич І.П. Шляхи та способи розв'язання політичних конфліктів. Вісник Київ. наи. ун-ту ім. Тараса Шевченка. Серія: Філософія. Політологія. 2007. Вип. 87-88. С. 128-132.

Статут Організації Об'єднаних Націй і Статут Міжнародного Суду. URL: https:/ zakon.rada.gov.ua/ laws/show/995_010.

\section{References}

Zakon Ukrayiny` «Pro zapobigannya korupciyi». URL: https://zakon.rada.gov.ua/laws/show/1700-18.

Vashhenko K.O., Korniyenko V.O. Politologiya dlya vchy`telya. URL: https://web.posibnyky.vntu.edu.ua/ fmib/13vashenko_politologiya_dlya_vchitelya/194.htm.

Konfliktologiya : navch. posib. / L.M. Gerasina, M.P. Trebin, V.D. Vodnik ta in. X. : Pravo, 2012. 128 s.

Dojch M. Hrestomatiya po politologiyi. Vy`rishennya konflikta (konstrukty`vni i destrukty`vni procesy`). URL: https://www.gumer.info/bibliotek_Buks/Psihol/Konflikt/05.php.

Stankevy`ch I.P. Polity`chny`j konflikt ta tehnologiya jogo zapobigannya. Visny`k Ky`yiv. nacz. un-tu im. Tarasa Shevchenka. Seriya: Filosofiya. Politologiya. 2007. Vy’p. 87-88. S. 70-73.

Stankevy`ch I.P. Shlyahy` ta sposoby`rozv'yazannya polity`chny`h konfliktiv. Visny`k Ky`yiv. nacz. un-tu im. Tarasa Shevchenka. Seriya: Filosofiya. Politologiya. 2007. Vy`p. 8-88. S. 128-132.

Statut Organizaciyi Ob'yednany`h Nacij i Statut Mizhnarodnogo Sudu. URL: https://zakon.rada.gov.ua/ laws/show/995_010.

\section{Анотація}

Заъгородня Ю. В. Форми впливу на політичний конфлікт: теоретичний аналіз. - Стаття.

У статті розглянуто трактування та використання наукової термінології впливу на політичний конфлікт на різних етапах його розвитку. Проведено порівняльний аналіз суміжних понять, визначено подібні та відмінні особливості в розрізі сучасної конфліктної активності в політичних процесах. У розвитку наукових досліджень формуються загальновизначені уявлення про можливі механізми впливу на розвиток та завершення політичного конфлікту, досить часто виникає підміна понять щодо подій конфлікту, який перебуває в активній фазі, а тому виникає необхідність у деталізації форм впливу на політичний конфлікт, їх теоретична та практична значимість у сучасному прояві. Здавалось, усі ці види впливу мають ключову мету, а саме обмеження ескалації конфліктної протидії та зменшення агресії сторін політичного конфлікту один до одного, однак під час формування стратегії політичного впливу їх бачення кінцевої точки конфлікту під час впливу досить часто різноспрямовані, а тому реалізувати їх та приборкати в такому разі ще важче. Подолання конфліктної активності сторін можна прирівняти до мистецтва дипломатії, коли невдачі в розв'язанні протиборства пояснюються складністю та латентністю політичних атак сторін, неможливістю вплинути та ситуацію, але досить рідко сторони визнають свої дії нетактовними. Подолання конфліктних атак $є$ найвагомішим показником бажання сторін до примирення, однак інколи це лише затягування конфлікту на більш тривалий час. Тому усі механізми впливу досить важливі залежно від ситуації та типу політичного конфлікту. А ефективне використання механізмів впливу на політичний конфлікт мінімізує негативні наслідки та допомагає розвивати політичну систему з урахуванням сучасних суспільних потреб. Доцільність та актуальність можливого впливу на суб'єктів протиборства чи конфлікт загалом є запорукою партнерства в майбутньому. Сучасний світ розширює масштаби впливу конфліктних політичних рішень та потребує детального аналізу.

Ключові слова: політичний конфлікт, регулювання, врегулювання, придушення, завершення.

\section{Summary}

Zavgorodnya $Y u$. V. Forms of influence on political conflict: a theoretical analysis. - Article.

The article discusses the interpretation and use of scientific terminology of influence on political conflict at different stages of its development. A comparative analysis of adjacent solutions is carried out, similar and different features in the context of modern conflict activity in political processes are identified. In the development of scientific research, generally defined ideas about the possible mechanisms of influencing the 
development and completion of political conflict are formed. practical significance in modern manifestation. It seems that all these types of influence have a key goal, namely to limit the escalation of conflict and reduce the aggression of the parties to the political conflict, but when forming a strategy of political influence, their visions of the end point of conflict are often divergent. in this case even more difficult. Overcoming the conflicting activity of the parties can be equated to the art of diplomacy, when failures in resolving the confrontation are explained by the complexity and latency of political attacks of the parties, the inability to influence the situation, but rarely do the parties recognize their actions tactless. Overcoming conflict attacks is the most important indicator of the parties' desire for reconciliation, but sometimes it is only prolonging the conflict for a longer period of time. Therefore, all mechanisms of influence are quite important depending on the situation and the type of political conflict. And the effective use of mechanisms to influence political conflict minimizes the negative consequences and helps to develop the political system taking into account modern social needs. The appropriateness and relevance of the possible impact on the parties to the conflict or the conflict in general is the key to a future partnership. The modern world is expanding the scope of the impact of conflicting policy decisions and needs detailed analysis.

Key words: political conflict, regulation, settlement, suppression, completion. 